\title{
A QUEST FOR IDENTITY: AN ONTOLOGICAL SURVEY OF KAFKAESQUE WORLD
}

Muhammad Adnan Akbar ${ }^{1 *}$, Eram Jamil ${ }^{2}$, Ihsan Ullah Khan ${ }^{3}$, Nijat Ullah Khan ${ }^{4}$

${ }^{1 *}$ Lecturer in English, Higher Education Department, Punjab, Pakistan, and Ph.D. Scholar, Department of English, Air University, Islamabad, Pakistan; ${ }^{2}$ Assistant Professor, Department of English, University of Sargodha, Bhakkar Campus, Pakistan; ${ }^{3}$ Assistant Professor, Department of English and Applied Linguistics, University of Science and Technology, Bannu, KP, Pakistan; ${ }^{4}$ Elementary and Secondary Education, KP, Peshawar, Pakistan.

Email: ${ }^{1 *}$ adnandhandla@gmail.com, ${ }^{2}$ eramjamillcwuj@gmail.com, ${ }^{3}$ ihsanlakki@yahoo.com, ${ }^{4}$ shahnijat@gmail.com Article History: Received on $15^{\text {th }}$ June 2021, Revised on $27^{\text {th }}$ June 2021, Published on $28^{\text {th }}$ June 2021

\section{Abstract}

Purpose of the Study: Franz Kafka is a much-debated existential writer who portrays existential traumas prevalent in his era. This research unfolds identity-related issues present in an existential journey of characters. Those are usually discussed in terms of existence and being. Identity formation, in an existential narrative, is seen in the process of becoming.

Methodology: This paper is an interpretive phenomenological study to unearth the phenomenon of identity. Heidegger's interpretive phenomenology, along with Sartre's ontological framework, will be used to analyze Kafka's two novels, The Trial and The Castle. Yet, his book, Amerika, is left as it is considered unfinished.

Findings: The Kafkaesque world pictures the traumas of the existential world, and this study mainly focuses on the phenomenon of identity, which is in constant flux in these ever-changing dimensions of the existential journey. Authentic and inauthentic existence, good and bad faith, is essential binaries in evaluating the identity of any character at any given instance.

Application of the Study: This study will contribute to the understanding of characters of the Kafkaesque world in the light of the identity issues from an ontological perspective. As characters of Kafka are constantly striving to achieve good faith and trying to abandon inauthentic existence to attain harmony with their existence.

Novelty/Originality of the Study: Kafka has been studied for many existential perspectives, yet this study explores the phenomenon of identity embedded in the existential narrative. Identity is usually sought in relation to discourse and postcolonial studies while discussing the Kafkaesque world. Yet, in this research, identity-related issues have been coupled with existential and ontological processes going in the fictional narrative of Kafka.

Keywords: Leveling, Identity, Herd, Becoming, Kafkaesque World, Being.

\section{INTRODUCTION}

Kafka was born in a Jewish family, and he was gifted and could speak three languages at a time (Sokel, 1999, p. 837). Knowledge of these languages enables him to open up a new frontier of possibilities for himself. Due to diversity and mastery of language, Kafka has always been discussed as a Janus-faced novelist. World War I, economic depression, industrialization, capitalism, and authoritarian roles were all approaches encompassing the landscape of Kafka's fiction. Kafka was writing at a time when scientific discoveries were accelerating, and everyday brought something new. Among scientific progress and depressing existential circumstances, Kafka was busy exposing bureaucratic and political tyranny. Prague witnessed all these socio-political conflicts, and Kafka documented them in his Kafkaesque World.

Kafka was a passive child who had no interest in socializing, so he remained aloof from his surroundings. He had a bad relationship with his father from childhood because his father was an authoritarian personality who tried to dictate everything in Kafka's life (Kafka, 1953, p.23). Kafka had a bad experience at school despite that he performed exceptionally well in the German language and culture. He had an aptitude for arts and gymnastics.

A lonely and alienated child, Kafka had a bead family life as he remained at odds with his father. There had been a never-ending battle between father and son that impacted his literary endeavor, and marked traces of this subjugation can be traced easily. Ernst Pawel, who is a biographer of Kafka, has observed this uneasy relationship and quotes as, "The father, with his crude selfishness, parvenu mentality, and mindless vulgarity, bore a large if the unwitting share of responsibility for his son's troubled childhood" (Pawel, 1984, p.58).

The Oedipal complex left an everlasting impact on Kafka's personality and whole life; he struggled to break the labyrinth of Janus-faced nature. The authoritarian and dictatorial character of the father made Kafka submissive and depressed, which can be observed from his fictional world. Kafka tried his best to neutralize his relationship with his father, but he failed in his attempt (Gray, 1973, p.31). The Metamorphosis (1915), The Judgment (1913), The Country Doctor (1919), The Castle (1926), and many more fictional pieces explore the complexities and discrepancies taking roots in the relation with his father. In his letter to his father, he confesses that his writings are those tears that he wanted to shed by keeping his head on his father's shoulder. He says in his letter, "a veiled expression of the fact that something is wrong in our 
relationship and that you have played your part in causing it to be so, but without its being your fault" (Kafka, 1953, p.31).

\section{The Rationale of the Study and Objective}

Kafka has been studied and analyzed through many similar perspectives. Yet, no work has been done while keeping in view the ontological position of identity-related issues prevailing in the Kafkaesque World. Identity has been studied on a thematic level in literature, yet the ontological and, more specifically, existential identity place has not been studied completely. Hence there is ample space to unfold this phenomenon from this particular angle. This research will focus on providing an ontological perspective of identity crisis in Kafka's fiction. This research further deciphers different dimensions of identity crisis and their possible explanations in the light of Sartrean and Heideggerian phenomenology.

\section{LITERATURE REVIEW}

Being a minority writer, identity crisis is a prevalent issue that has been dealt with in detail by Deleuze and Guattari in Kafka: Toward a Minor Literature which is a tricky and complicated analysis of the Kafkaesque World as this study does not follow the traditional model in a strict sense. Deleuze and Guattari assert that minority literature is always political as characters' interests are always linked with social and political concerns. According to them, minority writers use the language of the majority. Still, their treatment of language is quite different, and here, they hint at the creolization process, which they termed as the deterritorialization of the majority language. One more thing that this kind of literature is collective according to them, which means that characters in the art are representatives of the whole community at large. They included novels, short stories, diary entries, and letters for analysis, yet they did not analyze literary pieces systematically but based on convenience. Kafka belongs to the Jewish community, and both writers tried to decipher the mental capabilities of a minority writer. They have taken into account historical incidents and diary entries to understand the creative process fully. This study includes narrative mode, creative mode, and thematic mode in analysis to fully comprehend the meaning of whatever has been written (Deleuze \& Guttari, 1986, p.33). Lowell Edmund comments and rejects Deleuze and Guattari's stance. He says, "Kafka scholars have thoroughly castigated Gilles Deleuze and Felix Guattari for their misappropriation of Kafka's thoughts on minor literature and their misinterpretation of Kafka himself as a minor writer" (Edmund, 2010, p.351).

19th-century Europe witnessed sudden decline and disintegration of moral and social values. William Emirich observes this change and sees its impact on Franz Kafka. According to Emirich, scientific discoveries change the whole scenario altogether that nearly all issues like Christian discourses on immortality, Leist's thoughts about feeling, and even Goethe's literary ventures; have all been subjected to scientific inquiry. The novelistic art did not only tend to portray ethical dimensions but also propagated and inculcated certain norms in the society through its narrative. Novelistic art was considered a socially-oriented work that critiqued the patterns of society. In the 20th century, it became difficult to establish the social norms and order that Goethe envisioned. William Emirich minutely observes this change that is prevailing in the fiction. The result was that the artists gradually succumbed to accepting the society's criteria in which they worked, thus entering culture as it was in reality. To re-establish critical values, the artist was forced to become critical of these relative value systems, which fettered man even more than the earlier absolute values had. Only by negatively breaking down these arbitrary bonds could the artist reveal freedom, which is humanity's right. Emrich sees Kafka as a writer who attempts to re-establish this freedom and identity (Emrich, 1965, p.11).

The Kafkaesque World cannot be limited to any particular approach. That's why so many sociological, psychological, and theological standpoints help decipher Kafka's fiction characters (Akbar et al., 2021, p.404). In the presence of so many interdisciplinary approaches, Joseph K, Mr. K, Gregor Samsa, and many other characters cannot be comprehended fully. They provide a diversity of meanings whenever they are researched again due to their twisted and complicated narrative. "Kafka's fictional world is multidimensional, and every interpretation seems to suit it" (Akbar, 2017, p.220); that's why these popular approaches of theology, philosophy, and literary movements all become pretty relevant. It is necessary to comprehend reality from interdisciplinary perspectives as reality is not a fixed entity but is a dynamic process. This is the central problem in nearly all fictional pieces of Franz Kafka. As Judith Ryan opines, "But Kafka seems accessible to almost any methodology one might care to apply" (Ryan, 1985, p.257).

Martin Greenberg points out Kafka's naturalistic tendencies. Greenberg goes on to show Kafka's interest in scientific naturalism from his diaries. The prime characteristic of Kafka's naturalism is its emphasis on details, an emphasis that demands extreme close perception. This emphasis begins to have an overgrowing influence in Kafka's early work as naturalism evolves. Kafka observes the surroundings minutely and conveys those details by surrealistic rendering. His narrative style differentiates him from others in his approach towards reality. Consequently, the most trivial events have been treated with utmost seriousness and make them incomprehensible and astounding. Kafka's protagonists "begin to feel truth as it happens to them, not how, in the eyes of others, it is supposed to happen to them" (Greenberg, 1965, p.24$\underline{27)}$.

Margaret Church, in her argument, opines that Kafka writes of all sorts of human ventures ranging from ordinary events to most extraordinary happenings that cause multiple interpretations. Church deciphers intrinsic ambiguities in The Trail and The Caste that has been presented through the structure of the novels. She unfolds a quest for meaning as a major theme in these texts. (Church, 1960, p.20). 
Kafka is not a Jewish writer in a strict sense, yet his writings have traces of his Jewish identity. Jackals and Arabs are researched by Hmadan to see the patterns of Jewishness embodied in this text (Hamdan, 2019, p.2). Engle surveys the Kafkaesque world from the notion of religion, myth, and modernity. He systematically analyzes the modernistic narration of Kafka to see the patterns of myth and religion prevalent in the texts (Engel, 2019, p.5). Creighton reviews Allen There's endeavor to understand Kafka's The Castle. He observes complex structures that are a hindrance in any definite interpretation of Kafka, so the identity of the Kafkaesque world remained esoteric (Creighton, 2019, p.163).

\section{RESEARCH METHODOLOGY}

It is a qualitative research work, and this method has been adopted for in-depth exploration of ideas of ontology with relation to identity issues in Franz Kafka's fictional world. The qualitative approach will be helpful in the theorization of the framework. As ontology is philosophical speculation that deals with the study of being. Nothingness is a prominent element, and the theme of ontology as nothingness always appears with being, and it cannot be considered as a separate entity, so this study will examine the position of nothingness in different modes of being, which will provide a thorough understanding of the phenomenon. Later on, this phenomenon will be used as a tool of research. In this research, selected novels of Franz Kafka will be the base of this study that will be discussed with the help of a framework of ontology.

"Literature can be treated as a document in the history of ideas and philosophy, for literary history parallels and reflects intellectual history (Wellek \& Warren, 1956, p.111)." In light of this statement, it can be assumed that literature and philosophy are interconnected. The themes or issues in philosophy have been discussed in the different genres of literature. In poet-thinkers, we have Empedocles, Giordano Bruno, Goethe, Alexander Pope, John Donne, and John Milton. Christopher Marlowe and Shakespeare depicted the philosophical issues of Platonism, atheism in their works. George Eliot, James Joyce, Tolstoy, and Dostoyevsky are the distinguished names among many novelists whose work carried the philosophical touch. Hence literary figures intentionally or unintentionally referred to philosophical ideas.

"Being alludes to a condition of having a presence and existence. This existence provides the rationality of things, whether they are humans or objects. First comes the being, which is later followed by the thoughts, ideas, and actions" (Akbar \& khan, 2021, p. 2842). The very primary reason for all the activities is this being. Humans, animals, objects have their being, their existence, which is followed by the concerning deeds. This being highlights the sense of awareness, the awareness of presence which consequently leads to the relevant happenings. The topic of being has always been of great interest for western philosophy, and it dates back to the pre-Socratic philosophers who shed light on the discourse of being. Heraclitus (535CE-475 BCE) and Parmenides (520CE-450BCE) were the Greek philosophers who initiated the debate of being and non-being. Socrates in Metaphysics further discussed the questions relating to being. Gradually, the issue of being emerged as a school of thought in philosophy known as ontology.

In his book Being and Time, Martin Heidegger uses the term "Dasein," which means being there, which refers explicitly to human existence in this world. He argues that to comprehend human existence, it must be understood as being. The world is all around, and it has narrowed down the opportunities and space for a being. Being has to encounter a fixed set of circumstances. To elaborate this condition further, he mentions the term "Thrown" is an extension of the debate of the conditioned environment in which a being has to survive. In such pre-determined circumstances, the decisions taken by humans determine their beings. It gives meaning to their existence. Heidegger's other major work on ontology is The Hermeneutics of Facticity; in this book, he talks about the history of ontology and its relation with phenomenology, ideas of Hegel, Husserl, and Kierkegaard (Wheeler, 2020). Jean-Paul Sartre's work Being and Nothingness elaborates his ideas of ontology. According to Sartre, there are two kinds of being. "Ontological consciousness creates the consciousness of existence" (Akbar, 2017, p.206). One is "being for itself," which means the conscious stage of being and, the other category is "being-in-itself," which defines the unconscious background of being. "Being-for-itself" or being of consciousness is about the existing objects (ㅌynn, 2013).

\section{ANALYSIS AND DISCUSSION}

"In many ways, Kafka has structured the novel as if it represents an exercise in reason. In a philosophical account of reason, of course, this faculty would encompass not just the right use of logic, but also the correct intuition, or judgment of premises and principles" (Stringfellow, 1995, p.177). Joseph K. in The Trial suffers from the injustice and exposes the meaninglessness and absurdity of this life as going through several trials without any misconduct; it looks as a punishment itself searching for a crime. At the end of the novel, he runs towards the altar to get rid of that crazy life. Alberes and Boisdeffre comment, "in The Trial it is the individual who feels not only that he is fundamentally guilty" (Alberes \& Boisdeffre, 1967, p.64), Kafka narrates his tragic death as: "But the hands of one of the partner were already at K's throat... 'Like a dog! He said: it was as if he meant the shame of it to outlive him" (Kafka, n.d. p.558). As Sussman describes this novel, "In terms of the history of twentieth-century European literature, The Trial coincides with a far-reaching modernist experimentation... ( Sussman, 1993, p.4)".

We were thrown into this world one day, and we don't know the reason why we have been condemned to exist? Why have we not been given a choice to live or not? We struggle to solve this puzzle, and so many intellectuals are striving to answer this puzzle, but instead of deciphering it, it becomes complicated and causes estrangement for oneself. 
"Someone must have been telling lies about Joseph K. for without having done anything wrong he was arrested one fine morning (Kafka, n.d. p.406)". Joseph K., the novel's main protagonist, has been predestined to go through a meaningless vista of life. He has been arrested, but no reason for his arrest has been given. Pathetically, he has been forced to practice his normal daily activities because he is not a jailbird, but he is also (imprisoned) in another sense; "you are under arrest, certainly, but that need not hindering you from going about your business" (Kafka, n.d. p.415). From there onwards, Joseph K's existential journey starts when freedom has been given to defend him but not told about allegations against which he will have to defend himself.

Joseph K.'s animal self is quite evident from the start. It emerges in sexual activity with Fraulein Burstner: "kissed her first on the lips, then all over the face, like some thirsty animal lapping greedily at a spring of long-sought freshwater" (Kafka, n.d. p.425). He is not more than herd initially, yet he is condemned to find possibilities to create his essence that fulfills his entity with an enlightening revelation of being. Yet his struggle results in nothing significant, and he embraces nothingness by returning to his animal self. Chris Danta compares the death of Joseph K as a sacrificial animal in his article (Danta, 2007, p.721). Kafka narrates his death as;

But the hands of one of the partners were already at K's throat, while the other thrust the knife into his heart and turned it there twice. With failing eyes, K. cold still see the two of them, cheek leaning against cheek, immediately before his face, watching the final act. 'Like a dog!' he said: it was as if he meant the shame of it to outlive him (Kafka, n.d. p.558).

In The Castle, one can see a continuous struggle of Mr. K (a character) to confirm his identity as a land surveyor (Heller,1986, p.23). He is summoned as a land surveyor, but his position becomes uncertain on his arrival, and higher authorities are not ready to accept him as a land surveyor anymore. His identity comes under alarm, and he struggles to regain his position. He uses legal and illegal means to meet his ends, but everything fails. He even attracts the mistress of Klamm, a higher official from the castle, to bargain with him and does not turn out to be helpful. He tries to enter the castle premises to know the processes going in the castle, but his attempts result in disappointment. Castle becomes an inaccessible territory that is esoteric from the start of the novel as he narrates;

The castle hill was hidden, veiled in mist and darkness, nor was there even a glimmer of light show that the castle was there. On the wooden bridge leading from the main road to the village, $\mathrm{K}$. stood for a long time gazing into the illusory emptiness above him (Kafka, n.d. p.184).

K.'s endless struggle to access the castle is similar to Kafka, whose complete life is an attempt to capture a word of praise from his father. He was never on good terms with his father, yet the castle is replaceable with unseen walls between him and his father in this perspective. He wishes to intrude in the castle and longs to be Klamm's trustworthy one. In this sense, a replacement will result in an oedipal complex. Kafka, throughout his life, had an uneasy relationship with his father that was not resolved till death; much similar relation is developed between Klamm and K. and one more important thing is his engagement with Frieda (mistress of Klamm) that gives a transparent clue to his oedipal state.

Oedipalization shows his (K. and extent of Kafka's) fixation on one stage that stops the process of growth. He becomes a fixed entity like a herd and becomes seized. As Heller says, "Even the most mistaken religious interpretations of Kafka's writings show at least an awareness of its religious character, whereas the psychological analysis, in their devastating plausibility, tends to reduce them to symptoms of the oedipal complex" (Heller, 1986, p.85). In Kierkegaard's (Gardiner, 1988 , p.54) sense, his journey has been stopped in the second sphere (ethical sphere), and he is not able to move forward to embrace religious or spiritual self by annihilating the ethical sphere. His life has been lost in the maze of ethical panorama on one's life, and he is unable to defy his present situation. He is caged like a bird, yet he tries to fly to reach the sphere of the castle, but as Kafka says that heaven has no place for crows, so K. fails in his attempt. "Swarms of crows were circling round it" (Kafka, n.d., p.188). But they were not able to enter the castle.

Leveling is another evident factor that limits oneself to a fixed position. All future possibilities and doorways of change are closed to herd. In The Castle, one "inn looked very like the inn where K. was staying. All the houses in the village resemble each other more or less..." (Kafka, n.d., p.205), not only inns, but human beings are so much similar that K. is unable to distinguish between his two assistants, "The only difference between you is your name; otherwise, you're as like as snakes" (Kafka, n.d., p.195).

The Castle has a mysterious and exotic look, yet Eric Heller is not ready to accept it as something divinely that can have anything spiritual to offer to K., he comments;

There is no conceivable idea of divinity that could justify those interpreters who see in the Castle the residence of "divine law and divine grace." Its officers are totally indifferent to good if they are not wicked. Neither in their decrees nor their activities is there any trace of love, mercy, charity, or majesty (Heller, 1986, p.99).

If we accept the novel as religious and the castle as a symbol of divinity, then its theme will be the death of God as K.'s no plea has ever been answered by the Divine. He remains in longing for a way out from his confused state of mind by admission in the castle (divine), yet no door was opened for him; rather, he was misguided by a few fake or undependable officials. His quest results in bewilderment, and he cannot comprehend his state of nothingness when no 
God is there to give you any intrinsic meaning, but you have to create them by your own struggle, and for that purpose, one has not to direct his quest to something previously established. As Amereson provides with an interpretation of godless state;

The castle is godless but filled with people who retain a deep longing for the divine and the security a divinely-oriented (or otherwise certain) ethics promises. These old absolutes are no longer available if ever they were, but we humans have not yet adjusted to his state of affairs (Amerson, 1988, p.108).

As novels suggest, a crisis is happening somewhere in Kafka's personal life. Not only did his father contribute to his identity crisis, but his relationship with his female counterparts also enhanced his trauma of identity. Kafka's life is not empty from the presence of fairer sex, but they have no permanent place in his life and his fictional work. He is a misogynist, much like James Joyce. He and his characters are trying to fly away from the design of women. He was confused, and his characters are trying to fly away from the design of women. He was baffled by existential and psychological traumas. For that reason, he was, perhaps, unwilling to sacrifice his love for writing for a woman, who might have squeezed all intellectual capabilities from his mind. Mairowitz quotes him: "Women are traps which lie in wait for men, in order to drag them down into the Finite" (Mairowitz, 1993, p.127). He had a very short-lived relationship with Felice, Meline, and Dora due to this obsession. Alberes and Biosdeffre describe his anguish:

Thus, for days Kafka struggled against contradictions from which there is no escape-in a labyrinth in which he exhausts his mental strength in the attempt to overcome these contradictions - caught between fear of disappointing his fiancée by abandoning her and fear of destroying her by marrying her (Alberes and Biosdeffre, 1967, p.41).

To Miena, he wrote before, and after breaking the engagement, Mariowitz refers to this incident as, "After all, you are a girl, and you want a man, not an earthworm" (Mariowitz, 1993, p.66). "I had got some distance away from you, through my own efforts, although it was a bit like the worm who breaks away with its front part when someone steps on its tail end" (Mariowitz, 1993, p.68).

Kafka once told his friend to burn his whole work after his death, but his friend betrayed him. Max Brod, the biographer, and editor of most of Kafka's books was that disloyal friend who, by an act of treachery, blessed the world with an explanation of the horrible existential anguish of modern man (Ackermann, 1950, p.105).

Kafka's personal life is a pure reflection of his fictional characters like Joseph K, Mr. K, Gregor Samsa, and many more who are also suffering from identity loss and are unable to achieve uniform identity in the course of existential trauma which surrounds them. Kafka has never been a happy fellow in his life, and perplexity prevailed in all his actions as he abandoned romantic ventures to devote himself entirely to a writing career. Yet, he always felt a void which can be observed from his diary entries. "Felice comes as a rescuer, but he prefers to take refuge in his intellectual activity" (Akbar et al., 2021, p. 404). He broke with Felice twice, yet on his deathbed, he encountered Dora Diamond, who filled his life with new inspiration. Gilman describes her as "Dora was the promised cure for Franz, she would bring her Eastern health to cure him of his western nervousness" (Gilman, 2005, p.124). Chris Danta accurately sums up Kafka's plight in these words, "Dedication to literature causes the writer to avoid not merely living an ordinary life but also dying an ordinary death" (Danta, 2008, p.154). Mrs. Kafka's (Dora called herself after his death as Mrs. Kafka) lively entry, in his life, could not prevent his fate of being a bachelor like Sisyphus, as in his same day's entry, he relates himself with the most tragic figure of the existential realm;

There is in it also something of this feeling; matter no longer rest with you, unless you wish it so. In contrast, this feeling of those who have no children; it perpetually rests with you, whether you will or no, every moment, in the end, every never-racking moment, it perpetually rests with you, and without result. Sisyphus was a bachelor (Kafka, 1948, p.401).

\section{CONCLUSION}

Identity crisis is not only prevalent in Kafka's fictional narratives, but his life is also full of these issues as he struggled throughout his life for sustainable identity. His struggle is well documented in his fiction. The existential struggle is equally perturbing his life as the life of his characters. Perplexity and chaos prevalent in fiction and biography hinder any sincere attempt to give meaning to life. That's why the quest for identity remains the most prominent phenomenon as this quest becomes everlasting, and no answer for this is forthcoming. That's why anguish remained a constant in the life of characters and Kafka. A previous study depicts, "He is also a victim of existential anguish and surrounded by the absurdity of circumstances" (Akbar \& Khan, 2021, p.2841).

\section{LIMITATION AND STUDY FORWARD}

This research is limited to Kafka's two novels and his diary entries related to Felice. Further, this research does not include Sartre's phenomenological position, which may result in different understandings. This framework can be applied further to other fictional narratives of Franz Kafka and other existentialist writers. Identity can be studied in the existential realm by coupling both perspectives by including other ontologists and phenomenologists, which may increase the scope of theorization. 


\section{AUTHOR'S CONTRIBUTION}

Muhammad Adnan Akbar has written an abstract, literature review, and conclusion. He developed a theoretical framework and gathered data. He also maintained correspondence with the journal. Eram Jameel contributed to data collection and literature review. Dr. Ihsan Ullah Khan has done data interpretation and discussion. Dr. Nijat Ullah Khan has worked on literature after completing research.

\section{REFERENCE}

1. Ackermann, P. K. (1950). A History of Critical Writing on Franz Kafka. The German Quarterly, 23(2), 105113. https://doi.org/10.2307/401846

2. Akbar, M. A. (2017). Nothingness: Anguish, Refutation, Rebellion and Submission. Journal of Applied Environmental and Biological Sciences, 7(2), 204-210.

3. Akbar, M. A. (2017). Ontological Analysis of The Metamorphosis. Journal of Applied Environmental and Biological Sciences, 7(4), 220-224.

4. Akbar, M. A., \& Khan, N. U. (2021). Anguish and Nothingness in Kafka's "A Country Doctor" and "The Starvation Artist." Elementary Education Online, 20(4), 2835-2841.

5. Akbar, M. A., \& Khan, N. U. (2021). Question of Being in Kafkaesque World: An Ontological Study of Kafka's "Researches of A Dog" and "The Silence of Sirens." Elementary Education Online, 20(4), 2842-2848.

6. Akbar, M. A., Khan, N. U. \& Khan, I. U. (2021). Satire amidst Uncertainty and Transformation: A Comparative Study of The Metamorphosis and Gulliver's Travel. Multicultural Education, 7(3), 400-404.

7. Alberes, R. M. and Boisdeffre, P. D. (1967). Kafka: Torment of Man. Trans. Baskin Wade. London: Vision Press Limited.

8. Amerson, R. J. (1988). Power and Authority in The Castle. Harold Bloom (ed). Modern Critical Interpretations: Franz Kafka's The Castle. New York: Chelsea House Publishers.

9. Church, M. (1960). Kafka's A Country Doctor. Beebe, M. (ed). Literary Symbolism: An Introduction to the Interpretation of Literature. Belmont.

10. Creighton, M. (2019). Understanding Franz Kafka by Allen Thiher. German Studies Review, 42(1), $162-164$. https://doi.org/10.1353/gsr.2019.0019

11. Danta, C. (2007). Like a dog... Like a lamb: Becoming Sacrificial Animal in Kafka and Coetzee. New Literary History, 38(4), 721-737. https://doi.org/10.1353/nlh.2008.0011

12. Danta, C. (2008). Kafka's Mousetrap: The Fable of the Dying Voice. Sub Stance, 37(3), $153-168$. https://doi.org/10.1353/sub.0.0014

13. Deleuze, G., \& Guattari, F. (1986). Kafka: Toward a minor literature. Minneapolis: University of Minnesota Press.

14. Edmunds, L. (2010). Kafka on Minor Literature. German Studies Review, 33(2), 351-374.

15. Emrich, W. (1965). Franz Kafka: Portrait. Geist und Wiedergeist. Emrich (ed). Frankfurt.

16. Engel, M. (2019). Franz Kafka: Modernism, Modernity, Myth, and Religion. Ken Seigneurie (ed). $A$ Companion to World Literature. John Wiley \& Sons, Ltd. https://doi.org/10.1002/9781118635193.ctwl0238

17. Flynn, T. (2013, Fall). Jean-Paul Sartre. The Stanford Encyclopedia of Philosophy. Zalta, E. N. (ed.) Retrieved from https://plato.stanford.edu/archives/fall2013/entries/sartre/

18. Gardiner, P. (1988). Kierkegaard. New York: Oxford University Press.

19. Gilman, S. L. (2005). Franz Kafka. London: Reaktion Books Ltd.

20. Gray, R. (1973). Franz Kafka. London: Cambridge University Press.

21. Greenberg, M. (1965). The Terror of The Art: Franz Kafka and Modern Literature. New York.

22. Hamdan, M. (2019). Spatial ambiguity and the question of Jewish identity in Franz Kafka's Jackals and Arabs, The Explicator. https://doi.org/10.1080/00144940.2019.1626329

23. Heller, E. (1986). The Castle. Bloom, H. (ed). Modern Critical Views: Franz Kafka. New York: Chelsea House Publishers

24. Kafka, F. (1948). The Diaries of Franz Kafka (1910-23). Max Brod (ed). Great Britain: Penguin Books.

25. Kafka, F. (1953). Wedding Preparation in the Country and other Stories. England: Penguin Books.

26. Kafka, F. (n. d). Great Works of Franz Kafka. Delhi: Janco Publishers.

27. Mairowitz, D. Z. and Crumb, R. (1993). Kafka: For Beginners. Great Britain: Icon Books.

28. Pawel, E. (1984). The Nightmare of Reason: A Life of Franz Kafka. New York: Farrar, Straus, Giroux.

29. Ryan, J. (1985). Our Trial: Franz Kafka's Challenge to Literary Theory. A Forum on Fiction, 18(3), 257-266 https://doi.org/10.2307/1345791

30. Sokel, W. H. (1999). Kafka as a Jew. New Literary History, 30(4), 837-853. https://doi.org/10.1353 /nlh.1999.0052

31. Stringfellow, F. (1995). Kafka's Trail: Between 'The Republic' and Psychoanalysis. Cordozo Studies in Law and Literature, 7(2), 173-205. https://doi.org/10.1525/lal.1995.7.2.02a00050

32. Sussman, H. (1993). The Trial: Kafka's Unholy Trinity. New York: Twayne Publishers.

33. Wellek, R., \& Warren. A. (1956). Theory of Literature: Rene Wellek and Austin Warren. New York: Harcourt, Brace \& World. 
Humanities \& Social Sciences Reviews elSSN: 2395-6518, Vol 9, No 3, 2021, pp 1340-1346

https://doi.org/10.18510/hssr.2021.93133

34. Wheeler, M. (2020). Martin Heidegger. The Stanford Encyclopedia of Philosophy. Zalta, E. (ed.). Retrieved from https://plato.stanford.edu/archives/fall2020/entries/heidegger/ 